\title{
Designing a lessons learned model to improve the success of new product development in project oriented organizations
}

\author{
Ahmad Norang and Seyed Mirahmad Nooshin ${ }^{b^{*}}$
}

${ }^{a}$ Associate Professor, Department of Industrial Engineering, Imam Hossein University, Tehran, Iran ${ }^{b} P h D$ Student, Department of Industrial Engineering, Imam Hossein University, Tehran, Iran

\section{H R O N I C L E}

Article history:

Received September 5,2016

Received in revised format

October 2, 2016

Accepted October 15, 2016

Available online

October 17, 2016

Keywords:

Knowledge based organizations

Lessons learned

New product development

\section{A B S T R A C T}

Nowadays, project-based organizations need to utilize intellectual capital and knowledge to become leader in their business activities. The new approach to use knowledge based skills from one side and development of the new complicated products from the other side have increased the need for designing a lessons learned model. The purpose of this paper is to design a lessons learned model to improve the success of new product development for project oriented organizations. The study designs a questionnaire in Likert scale and distributes it among 56 experts who were well informed about various techniques of new product development and lessons learned. Cronbach alphas for all components of the survey were well above the desirable level. The results of the survey have indicated that there were positive and meaningful relationships between lessons learned components and the success of the new product development.

\section{Introduction}

Professionals and executives in any organization preserve precious assets with valuable experiences and knowledge (Goffin \& Koners, 2011; Holzmann, 2013). When an expert is retired, a significant amount of experiences may be lost within organization and gaining such experience increase the costs of organizations, significantly (Milton, 2005, 2010). Recording knowledge and experiences create organizational memory and contributes to intellectual assets (Lantada et al., 2013). In other words, many engineers and managers normally express the desire to learn from the past project experience and they normally do not learn effectively from their present projects. The failure to learn valid and valuable lessons from project experiences can be contributed to a number of cognitive and social issues (Duhon \& Elias, 2008). According to Duffield and Whitty (2012), a substantial challenge for government and business project organizations is to make sure that lessons are learned and the mistakes of the past would not be repeated. The explicit management of project experience through lessons learned on project planning and execution has become of strategic importance for several firms (Tautz et al., 2010). Vandeville and Shaikh (1999) described a structured method for gathering "lessons learned"

* Corresponding author. Tel: +98-912 1387426

E-mail address: mirahmad.nooshin@gmail.com (S. M. Nooshin) 
information obtained from system development projects. Weber et al. (2001) surveyed lessons learned processes and systems, detailed their capabilities and limitations, examined lessons learned system design issues, and determined how artificial intelligence technologies could add to knowledge management solutions for these systems. According to Williams (2007, 2008, 2009), a key for successful project management is the capability to glean key learning's from the experience throughout the lifecycle of the project but the lessons learned from a special project would rarely incorporated into a firm's overall policies and procedures. Without a focused effort to gain on specific project learning's, lessons may be lost, mistakes could be repeated and opportunities for operational efficiency could be missed. During the past few years, there have been tremendous studies on lessons' learned and Table 1 describes different attributes discussed.

\section{Table 1}

The summary of the studies associated with lessons' learned and attributes

\begin{tabular}{|c|c|}
\hline Attribute & Source \\
\hline Being leader & $\begin{array}{l}\text { Mihm, 2012; Garside, 1999; Kessler \& Chakrabarti, 1996; Hobday, 2000; Williams, } \\
\text { 1999, 2007, 2008; Ohno, 1988; Weber et al., 2000, 2001; Murmann, } 1994\end{array}$ \\
\hline Communication, Environmental factors & $\begin{array}{l}\text { Mihm, 2012; Hobday, 2000; Cooper \& Kleinschmidt, 1993; Cooper, 1994; Cooper et } \\
\text { al., 2004; Kessler \& Chakrabarti, 1996; Milton, 2005; } 2010\end{array}$ \\
\hline $\begin{array}{l}\text { Optimization of repeated operations; } \\
\text { Inside organization solutions; Determine } \\
\text { the size and complexity of the project } \\
\text { cycle time and project failure }\end{array}$ & $\begin{array}{l}\text { Clark, 1989; Clark \& Fujimoto, 1991; Levinthal, 1997; Love et al., 2005; Kung, 2013; } \\
\text { Lake, 1991; Lynn et al., 1999; Nonaka et al., 1994; O'Reilly \& Tushman, } 2013\end{array}$ \\
\hline Department; Activity; Decision making & $\begin{array}{l}\text { Saren, 1984; Hobday, 2000; Milton, 2005, 2010; Cooper \& Kleinschmidt, 1993; Parry } \\
\text { et al., 2008; Parry et al., 2008; Haque \& Moore, 2004; Ohno, 1988; Kotnour, 2000; } \\
\text { Dawes, 2009; DeFillippi \& Arthur, 1998; Cooper et al., } 2004\end{array}$ \\
\hline $\begin{array}{l}\text { Validation; Implementation; production } \\
\text { support }\end{array}$ & $\begin{array}{l}\text { Duhon \& Elias, 2008; DeFillippi \& Arthur, 1998; Haque \& James-Moore, 2004, 2005; } \\
\text { Milton, 2005; 2010; Parry et al., 2008; Clark, 1989; Clark \& Fujimoto, } 1991\end{array}$ \\
\hline Concurrent engineering & Smith \& Eppinger, 1997; Grabher, 2002; Ahmadi \& Wang, 1999; Ha \& Porteus, 1995 \\
\hline Cost reduction & $\begin{array}{l}\text { Kessler \& Chakrabarti, 1996; Von Zedtwitz, 2002; Ohno, 1988; Williams, 1999, 2007, } \\
\text { 2008; DeFillippi \& Arthur, 1998; Roemer et al., 2008; Dröge et al., } 2000\end{array}$ \\
\hline Organizational capacity & $\begin{array}{l}\text { Williams, 2007; Weber et al., 2001; Haque \& James-Moore, 2004; Haque \& Moore, } \\
\text { 2005; Haque \& Moore, 2004; Khuri et al., 1993; Cooper et al., 2004 }\end{array}$ \\
\hline $\begin{array}{l}\text { Product innovation; having suitable } \\
\text { production schedule; top management } \\
\text { cooperation; limited innovation; project } \\
\text { leadership; survey on competitors; } \\
\text { teamwork selection; outsourcing }\end{array}$ & $\begin{array}{l}\text { Khuri et al., 1993; Cooper et al., 2004; Love et al., 2005; Clark \& Fujimoto, 1991; } \\
\text { Lindner \& Wald, 2011; Von Zedtwitz, 2002; Disterer, 2002; Biggs \& Justice, 2011; } \\
\text { Johnson et al., 2000; Julian, 2008; Nemoto et al., 2015; O'Dell \& Hubert, 2011; Roemer } \\
\text { et al., } 2000\end{array}$ \\
\hline Decision support system & DeFillippi \& Arthur, 1998; Grabher, 2002; Murmann, 1994 \\
\hline $\begin{array}{l}\text { Industry type; production development; } \\
\text { network marketing }\end{array}$ & Eisenhardt \& Tabrizi, 1995; Khuri et al., 1993; Lindner \& Wald, 2011 \\
\hline New product development; risk taking & $\begin{array}{l}\text { Milton, 2005, 2010; Balachandra \& Friar, 1997; Kong et al., 2015; Abrantes \& } \\
\text { Figueiredo, 2015; Darejeh \& Singh, 2014; Everaert \& Swenson, } 2014\end{array}$ \\
\hline Agile production planning & Weber et al., 2000; Milton, 2010; Hanafy \& ElMaraghy, 2015 \\
\hline Team learning & Kong et al., 2015; Flora et al., 2014; O'Leary \& Selfridge, 2000 \\
\hline $\begin{array}{l}\text { Recording experiences; publishing } \\
\text { achievements; Knowledge sharing }\end{array}$ & Rajagopalan, 2014; Ren et al., 2003; Saren, 1984 \\
\hline $\begin{array}{l}\text { Collecting common mistakes; Checklist; } \\
\text { emphasis on successes, Integration, } \\
\text { feedback usage }\end{array}$ & Flora et al., 2014; Simon, 1991 \\
\hline
\end{tabular}

\section{The proposed study}

The purpose of this paper is to design a lessons learned model to improve the success of new product development for project oriented organizations. The study designs a questionnaire in Likert scale and distributes it among 56 experts who were well informed about various techniques of new product development and lessons learned. Cronbach alphas for all components of the survey were well above the desirable level. Based on the survey accomplished, we develop a conceptual model for the proposed study of this paper as shown in Fig. 1 as follows 


\begin{tabular}{|c|c|c|}
\hline \multirow{5}{*}{ 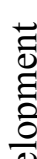 } & \multirow{3}{*}{ Capability } & Learning \\
\hline & & Skills \\
\hline & & Experience \\
\hline & \multirow[t]{2}{*}{ Objectives } & Common strategies \\
\hline & & Common goals \\
\hline 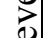 & \multirow{5}{*}{ Customer orientation } & Organizational identity \\
\hline 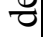 & & Network marketing \\
\hline$\ddot{0}$ & & Trust \\
\hline & & Loyalty \\
\hline ○ी & & Customer requests \\
\hline 2 & \multirow{4}{*}{ Organization } & Networking \\
\hline 3 & & Team working \\
\hline 0 & & Participation \\
\hline 4 & & Planning \\
\hline 임 & \multirow{3}{*}{ Process } & Continuous improvement \\
\hline की & & Change management \\
\hline త్ర & & Reengineering \\
\hline$\stackrel{0}{=}$ & \multirow[t]{2}{*}{ Intellectual property } & Copyright \\
\hline 只 & & Patent registration \\
\hline & \multirow{4}{*}{ System } & Management system \\
\hline 0 & & Financial system \\
\hline 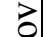 & & Knowledge management \\
\hline & & Professor of discipleship \\
\hline है & \multirow[t]{2}{*}{ Culture } & Culture \\
\hline & & Delegation of authority \\
\hline$\stackrel{0}{\circ}$ & \multirow{3}{*}{ Organizational structure } & Instruction \\
\hline 0 & & Integration \\
\hline 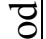 & & Knowledge structure \\
\hline . & \multirow{3}{*}{ Organizational capacity } & Environment \\
\hline 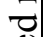 & & Analyzing organization \\
\hline 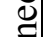 & & Market development \\
\hline 㓂 & \multirow{3}{*}{ Knowledge } & Awareness \\
\hline 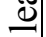 & & Individual creativity \\
\hline 2 & & Organizational creativity \\
\hline 잉 & \multirow{4}{*}{ Trust } & Motivation \\
\hline מ & & Job satisfaction \\
\hline & & Commitment \\
\hline & & Risk taking \\
\hline
\end{tabular}

Fig. 1. The conceptual model

We have performed an in-depth interview with some experts to learn more about the effects of different factors influencing on the success of new product development. In addition, we have coded every item obtained from the questionnaire in three digits. The first part of the code starts with a letter $\mathrm{P}$, which represents the key point. The second part of the code refers to different interviews on various case studies and the last part states the key number in the questionnaire. For instance, PB8 represents the eighth key point from the interview on case study B. We have performed 14 interviews with experts and extracted 6 key points from the second interview, 5 key points from the third interview, 8 key points from the fourth interview, 9 key points from the fifth interview, 11 points from the sixth interview, 12 points from the seventh interview and 4 points from the eighth interview. Table 2 demonstrates the open cases, which have become clear on case study A.

\section{Table 2}

The key open issues for case study A

\begin{tabular}{cll}
\hline Index & Description & Open code \\
\hline $\mathrm{PA}_{\mathrm{x}} 1$ & $\begin{array}{l}\text { Paying attention to intelligence equipment helps us depend on strong research and development to } \\
\text { advance the success. }\end{array}$ & $\begin{array}{l}\text { Knowledge based } \\
\text { system }\end{array}$ \\
$\mathrm{PA}_{\mathrm{x}} 2$ & $\begin{array}{l}\text { Paying attention to the fact that our new achievement has come from our past experiences. } \\
\mathrm{PA}_{\mathrm{x}} 3\end{array}$ & $\begin{array}{l}\text { Normally, there must be a strong believe to trust to highly educated people. } \\
\text { Experience }\end{array}$ \\
$\mathrm{PA} 4$ & New product development has to be involved with all departments. & $\begin{array}{l}\text { Commitment } \\
\text { Creativity and } \\
\text { innovation }\end{array}$ \\
& & Satisfaction \\
$\mathrm{PA}_{\mathbf{x}} 5$ & Taking care of human resources is the most important efforts in any organization. & Motivation \\
$\mathrm{PA}_{\mathrm{x}} 6$ & & \\
\hline
\end{tabular}


After having extensive interview with different experts, we have prepared a questionnaire in Likert scale and distributed among 56 experts. Cronbach alpha was within desirable level. In addition, Kolmogorov Smirnov test has indicated that the distribution of the data was normally distributed. Next, we present details of our findings.

\section{The results}

In this section, we present the results of the effects of different factors associated with lessons' learned on new product development. Table 3 presents the results of t-student test.

Table 3

The results of t-student test on relationship between lessons' learned and new product development

\begin{tabular}{|c|c|c|c|c|c|c|}
\hline & \multicolumn{6}{|c|}{ Test Value $=3$} \\
\hline & \multirow{2}{*}{$\mathrm{t}$} & \multirow{2}{*}{ df } & \multirow{2}{*}{ Sig. (2-tailed) } & \multirow{2}{*}{ Mean Difference } & \multicolumn{2}{|c|}{$95 \%$ Confidence Interval of the Difference } \\
\hline & & & & & Lower & Upper \\
\hline New product development & 37.658 & 55 & .000 & 1.56604 & 1.4827 & 1.6494 \\
\hline Lessons' learned & 34.351 & 55 & .000 & 1.55198 & 1.4614 & 1.6425 \\
\hline Relationship & 36.215 & 54 & .000 & 1.50639 & 1.4230 & 1.5898 \\
\hline
\end{tabular}

As we can observe from the results of Table 3, the relationship between new product development and lessens' learned are statistically significant. Table 4 shows the results of t-student values for different components of new product development. Again, all statistics are within desirable levels. Table 5 shows the results of t-student values on examining the sub-components of the lessons' learned. Finally, Table 6 shows the results of the implementation of lessons' learned on new product development and as we can observe there were positive and meaningful relationships between different factors associated with lessons' learned and new product development.

\section{Table 4}

The result of $\mathrm{t}$-student on validating new product development

\begin{tabular}{|c|c|c|c|c|c|c|}
\hline & \multicolumn{6}{|c|}{ Test Value $=3$} \\
\hline & \multirow[t]{2}{*}{$\mathrm{t}$} & \multirow[t]{2}{*}{$\mathrm{df}$} & \multirow[t]{2}{*}{ Sig. (2-tailed) } & \multirow[t]{2}{*}{ Mean Difference } & \multicolumn{2}{|c|}{$\begin{array}{l}95 \% \text { Confidence Interval of the } \\
\text { Difference }\end{array}$} \\
\hline & & & & & Lower & Upper \\
\hline Competence and capability & 32.608 & 55 & .000 & 1.60119 & 1.5028 & 1.6996 \\
\hline Attitude & 30.413 & 55 & .000 & 1.56122 & 1.4583 & 1.6641 \\
\hline Knowledge & 22.837 & 55 & .000 & 1.53571 & 1.4009 & 1.6705 \\
\hline Teaching and learning & 23.550 & 55 & .000 & 1.57143 & 1.4377 & 1.7052 \\
\hline Skills & 24.405 & 55 & .000 & 1.60714 & 1.4752 & 1.7391 \\
\hline Experience & 20.273 & 55 & .000 & 1.60714 & 1.4483 & 1.7660 \\
\hline Motivation & 18.715 & 55 & .000 & 1.57143 & 1.4032 & 1.7397 \\
\hline Job satisfaction & 24.893 & 55 & .000 & 1.62500 & 1.4942 & 1.7558 \\
\hline Commitment & 24.893 & 55 & .000 & 1.62500 & 1.4942 & 1.7558 \\
\hline Ethics & 18.200 & 55 & .000 & 1.53571 & 1.3666 & 1.7048 \\
\hline Risk taking & 15.959 & 55 & .000 & 1.46429 & 1.2804 & 1.6482 \\
\hline Forecasting & 24.405 & 55 & .000 & 1.60714 & 1.4752 & 1.7391 \\
\hline Awareness & 17.354 & 55 & .000 & 1.46429 & 1.2952 & 1.6334 \\
\hline Creativity and innovation & 21.998 & 55 & .000 & 1.48214 & 1.3471 & 1.6172 \\
\hline Environment & 23.550 & 55 & .000 & 1.57143 & 1.4377 & 1.7052 \\
\hline System analysis & 24.405 & 55 & .000 & 1.60714 & 1.4752 & 1.7391 \\
\hline
\end{tabular}


Table 5

The results of testing the sub-factors influencing on lessons' learned

\begin{tabular}{|c|c|c|c|c|c|c|}
\hline & \multicolumn{6}{|c|}{ Test Value $=3$} \\
\hline & \multirow[t]{2}{*}{$\mathrm{t}$} & \multirow[t]{2}{*}{$\mathrm{df}$} & \multirow{2}{*}{ Sig. (2-tailed) } & \multirow{2}{*}{$\begin{array}{c}\text { Mean } \\
\text { Difference }\end{array}$} & \multicolumn{2}{|c|}{$\begin{array}{l}\text { 95\% Confidence Interval of the } \\
\text { Difference }\end{array}$} \\
\hline & & & & & Lower & Upper \\
\hline Norms, beliefs and values & 16.727 & 55 & .000 & 1.39286 & 1.2260 & 1.5597 \\
\hline $\begin{array}{l}\text { Having solidarity and common vision and } \\
\text { policies of the organization }\end{array}$ & 15.060 & 55 & .000 & 1.42857 & 1.2385 & 1.6187 \\
\hline The tolerability of staff & 26.655 & 55 & .000 & 1.67857 & 1.5524 & 1.8048 \\
\hline $\begin{array}{l}\text { Working with contractors to create a common } \\
\text { network products }\end{array}$ & 16.526 & 55 & .000 & 1.51786 & 1.3338 & 1.7019 \\
\hline $\begin{array}{l}\text { Loyalty, commitment and integrity of the } \\
\text { organization to customers }\end{array}$ & 26.655 & 55 & .000 & 1.67857 & 1.5524 & 1.8048 \\
\hline $\begin{array}{l}\text { The centrality of ethics in the relationship } \\
\text { between organizations and customers }\end{array}$ & 24.405 & 55 & .000 & 1.60714 & 1.4752 & 1.7391 \\
\hline Customer relationship network & 24.405 & 55 & .000 & 1.60714 & 1.4752 & 1.7391 \\
\hline $\begin{array}{l}\text { Possession of a valid image (brand) among } \\
\text { clients }\end{array}$ & 24.405 & 55 & .000 & 1.60714 & 1.4752 & 1.7391 \\
\hline $\begin{array}{l}\text { Organization's structure and relationships } \\
\text { between employees }\end{array}$ & 15.959 & 55 & .000 & 1.46429 & 1.2804 & 1.6482 \\
\hline $\begin{array}{l}\text { the ability to perform activities in the form of } \\
\text { teamwork }\end{array}$ & 26.655 & 55 & .000 & 1.67857 & 1.5524 & 1.8048 \\
\hline $\begin{array}{l}\text { Organizations and associations active in the } \\
\text { organization }\end{array}$ & 19.642 & 55 & .000 & 1.57143 & 1.4111 & 1.7318 \\
\hline Appropriate structure in the network & 27.362 & 55 & .000 & 1.69643 & 1.5722 & 1.8207 \\
\hline Network relationships among members & 19.946 & 55 & .000 & 1.58929 & 1.4296 & 1.7490 \\
\hline Succession planning system & 16.526 & 55 & .000 & 1.51786 & 1.3338 & 1.7019 \\
\hline $\begin{array}{l}\text { Knowledge management and recording } \\
\text { experiences }\end{array}$ & 24.405 & 55 & .000 & 1.60714 & 1.4752 & 1.7391 \\
\hline Financial system & 26.655 & 55 & .000 & 1.67857 & 1.5524 & 1.8048 \\
\hline Delegation of authority & 15.060 & 55 & .000 & 1.42857 & 1.2385 & 1.6187 \\
\hline
\end{tabular}

\section{Table 6}

The results of the implementation of lessons' learned on new product development

\begin{tabular}{|c|c|c|c|c|c|c|}
\hline & \multicolumn{6}{|c|}{ Test Value $=3$} \\
\hline & \multirow[b]{2}{*}{$\mathrm{t}$} & \multirow[b]{2}{*}{$\mathrm{df}$} & \multirow{2}{*}{$\begin{array}{l}\text { Sig. (2- } \\
\text { tailed) }\end{array}$} & \multirow{2}{*}{$\begin{array}{c}\text { Mean } \\
\text { Difference }\end{array}$} & \multicolumn{2}{|c|}{$\begin{array}{c}95 \% \text { Confidence Interval of } \\
\text { the Difference }\end{array}$} \\
\hline & & & & & Lower & Upper \\
\hline Goals and organizational strategies & 19.877 & 55 & .000 & 1.56250 & 1.4050 & 1.7200 \\
\hline Organizing & 23.085 & 55 & .000 & 1.51786 & 1.3861 & 1.6496 \\
\hline Customer oriented & 26.785 & 55 & .000 & 1.54911 & 1.4332 & 1.6650 \\
\hline Vision and common policy & 16.863 & 55 & .000 & 1.23810 & 1.0910 & 1.3852 \\
\hline Common ideas & 21.603 & 55 & .000 & 1.46429 & 1.3284 & 1.6001 \\
\hline Common goals and precedents & 24.405 & 54 & .000 & 1.57273 & 1.4435 & 1.7019 \\
\hline Contractors Network & 23.019 & 54 & .000 & 1.44545 & 1.3196 & 1.5714 \\
\hline Tolerability & 24.017 & 55 & .000 & 1.45714 & 1.3356 & 1.5787 \\
\hline Customer intelligence and customer demands & 27.667 & 55 & .000 & 1.62500 & 1.5073 & 1.7427 \\
\hline Customer Relationship Network & 21.397 & 55 & .000 & 1.66071 & 1.5052 & 1.8163 \\
\hline Honesty and trust & 19.092 & 55 & .000 & 1.53571 & 1.3745 & 1.6969 \\
\hline Communication & 23.177 & 55 & .000 & 1.55357 & 1.4192 & 1.6879 \\
\hline Ethics & 23.177 & 55 & .000 & 1.55357 & 1.4192 & 1.6879 \\
\hline Organization identity & 18.022 & 55 & .000 & 1.44643 & 1.2856 & 1.6073 \\
\hline Networking & 23.177 & 55 & .000 & 1.55357 & 1.4192 & 1.6879 \\
\hline Team work & 24.405 & 55 & .000 & 1.60714 & 1.4752 & 1.7391 \\
\hline Type of organizing teams & 23.177 & 55 & .000 & 1.55357 & 1.4192 & 1.6879 \\
\hline
\end{tabular}




\section{Conclusion}

In this paper, we have presented a comprehensive model to the review the effects of different components of lessens' learned on the success of new product development. The proposed study has gathered all the existing factors mentioned in the literature and using various comprehensive interviews with experts determined positive and meaningful relationships between lessens' learned and new product development. The study has implemented for project-based organizations and has determined that intellectual properties were important components of such organizations. It also appears that the success of any new product development is highly influenced from the past experiences. Therefore, it is important to record all positive/negative experiences and use them for new tasks. In fact, by acquiring new capabilities and power of creativity and innovation, human capital, organizational advantages, project-based organizations can make changes.

\section{References}

Abrantes, R., \& Figueiredo, J. (2015). Resource management process framework for dynamic NPD portfolios. International Journal of Project Management, 33(6), 1274-1288.

Ahmadi, R., \& Wang, R. H. (1999). Managing development risk in product design processes. Operations Research, 47(2), 235-246.

Balachandra, R., \& Friar, J. H. (1997). Factors for success in R\&D projects and new product innovation: a contextual framework. IEEE Transactions on Engineering management, 44(3), 276-287.

Biggs, B. I. L. L. Y., \& Justice, R. (2011). Mobile Learning: The Next Evolution. Chief Learning Officer, 10(4), 38-41.

Clark, K. B. (1989). Project scope and project performance: the effect of parts strategy and supplier involvement on product development.Management science, 35(10), 1247-1263.

Clark, K. B., \& Fujimoto, T. (1991). Product development performance: Strategy, organization, and management in the world auto industry. Harvard Business Press.

Cooper, R. G., \& Kleinschmidt, E. J. (1993). Stage gate systems for new product success. Marketing Management, 1(4), 20-29.

Cooper, R. G. (1994). Third-generation new product processes. Journal of product innovation management, 11(1), 3-14.

Cooper, R. G., Edgett, S. J., \& Kleinschmidt, E. J. (2004). Benchmarking best NPD practices-III. ResearchTechnology Management, 47(6), 43-55.

Darejeh, A., \& Singh, D. (2014). An investigation on Ribbon interface design guidelines for people with less computer literacy. Computer Standards \& Interfaces, 36(5), 808-820.

Dawes, R. (2009). House of cards. Simon and Schuster.

DeFillippi, R. J., \& Arthur, M. B. (1998). Paradox in project-based enterprise: the case of film making. California management review, 40(2), 125-139.

Disterer, G. (2002). Management of project knowledge and experiences. Journal of Knowledge Management, 6(5), 512-520.

Dröge, C., Jayaram, J., \& Vickery, S. K. (2000). The ability to minimize the timing of new product development and introduction: an examination of antecedent factors in the North American automobile supplier industry. Journal of Product Innovation Management, 17(1), 24-40.

Duffield, S., \& Whitty, J. (2012, August). A systemic lessons learned and captured knowledge (SLLCK) model for project organizations. In Proceedings of the 9th Annual Project Management Australia Conference (PMOz 2012)(pp. 4-18). EventCorp.

Duhon, H. J., \& Elias, J. S. (2008). Why it is difficult to learn lessons: insights from decision theory and cognitive science. SPE Projects, Facilities \& Construction, 3(03), 1-7.

Eisenhardt, K. M., \& Tabrizi, B. N. (1995). Accelerating adaptive processes: Product innovation in the global computer industry. Administrative science quarterly, 40(1), 84-110.

Eppinger, S. D. (1991). Model-based approaches to managing concurrent engineering. Journal of Engineering Design, 2(4), 283-290.

Eppinger, S. D., Whitney, D. E., Smith, R. P., \& Gebala, D. A. (1994). A model-based method for organizing tasks in product development. Research in Engineering Design, 6(1), 1-13. 
Everaert, P., \& Swenson, D. W. (2014). Truck redesign case: Simulating the target costing process in a product design environment. Issues in Accounting Education Teaching Notes, 29(1), 110-128.

Flora, H. K., Wang, X., \& Chande, S. V. (2014). An investigation into mobile application development processes: Challenges and best practices. International Journal of Modern Education and Computer Science, 6(6), 1.

Grabher, G. (2002). Cool projects, boring institutions: temporary collaboration in social context. Regional studies, 36(3), 205-214.

Garside, J. (1999). Plan to win: a definitive guide to business processes. Purdue University Press.

Goffin, K., \& Koners, U. (2011). Tacit knowledge, lessons learnt, and new product development. Journal of Product Innovation Management, 28(2), 300-318.

Guide, A. (2001). Project Management Body of Knowledge. In Project Management Institute.

Ha, A. Y., \& Porteus, E. L. (1995). Optimal timing of reviews in concurrent design for manufacturability. Management Science, 41(9), 1431-1447.

Haque, B., \& James-Moore, M. (2004). Applying lean thinking to new product introduction. Journal of Engineering Design, 15(1), 1-31.

Haque, B., \& James-Moore, M. (2005). Performance measurement experiences in aerospace product development processes. International Journal of Business Performance Management, 7(1), 100-122.

Haque, B., \& Moore, M. J. (2004). Measures of performance for lean product introduction in the aerospace industry. Proceedings of the Institution of Mechanical Engineers, Part B: Journal of Engineering Manufacture, 218(10), 1387-1398.

Hanafy, M., \& ElMaraghy, H. (2015). A modular product multi-platform configuration model. International Journal of Computer Integrated Manufacturing, 28(9), 999-1014.

Hobday, M. (2000). The project-based organisation: an ideal form for managing complex products and systems?. Research policy, 29(7), 871-893.

Holzmann, G. J. (2013). Landing a spacecraft on Mars. IEEE software, 30(2), 83-86.

Johnson, C., Birnbaum, L., Bareiss, R., \& Hinrichs, T. (2000). War stories: Harnessing organizational memories to support task performance. Intelligence, 11(1), 16-31.

Julian, J. (2008). How project management office leaders facilitate cross-project learning and continuous improvement. Project Management Journal, 39(3), 43-58.

Kessler, E. H., \& Chakrabarti, A. K. (1996). Innovation speed: A conceptual model of context, antecedents, and outcomes. Academy of Management Review, 21(4), 1143-1191.

Khuri, F., Plevyak, J., \& Howard, M. (1993). An Investigation of Integrated Product Development Implementation Issues: A Case Study of Bosma Machine and Tool Corp.

Kong, T., Li, G., Feng, T., \& Sun, L. (2015). Effects of marketing-manufacturing integration across stages of new product development on performance. International Journal of Production Research, 53(8), 2269-2284.

Kotnour, T. (2000). Organizational learning practices in the project management environment. International Journal of Quality \& Reliability Management, 17(4/5), 393-406.

Kung, S. H. (2013). Seamless design approach for mobile applications. International Journal of Advancements in Computing Technology, 5(13), 532.

Lake, J. G. (1991). Concurrent Engineering: A New Initiative. Program Manager, 18-26.

Lantada, A. D., Morgado, P. L., Muñoz-Guijosa, J. M., Sanz, J. L. M., Otero, J. E., García, J. M., ... \& de la Guerra Ochoa, E. (2013). Towards successful project-based teaching-learning experiences in engineering education. International Journal of Engineering Education, 29(2), 476-490.

Levinthal, D. A. (1997). Adaptation on rugged landscapes. Management science, 43(7), 934-950.

Lindner, F., \& Wald, A. (2011). Success factors of knowledge management in temporary organizations. International Journal of project management, 29(7), 877-888.

Love, P. E., Fong, P. S. W., \& Irani, Z. (2005). Management of knowledge in project environments. Routledge.

Lynn, G. S., Skov, R. B., \& Abel, K. D. (1999). Practices that support team learning and their impact on speed to market and new product success. Journal of Product Innovation Management, 16(5), 439-454.

Mihm, J. (2012). Complexity in new product development: mastering the dynamics of engineering projects. Springer Science \& Business Media.

Milton, N. J. (2005). Knowledge Management for teams and projects. Oxford: Chandos.

Milton, N. (2010). The Lessons Learned Handbook: Practical approaches to learning from experience. Elsevier.

Murmann, P. A. (1994). Expected development time reductions in the German mechanical engineering industry. Journal of Product Innovation Management, 11(3), 236-252.

Nemoto, Y., Akasaka, F., \& Shimomura, Y. (2015). A framework for managing and utilizing product-service system design knowledge. Production Planning \& Control, 26(14-15), 1278-1289. 
Nonaka, I., Byosiere, P., Borucki, C. C., \& Konno, N. (1994). Organizational knowledge creation theory: a first comprehensive test. International Business Review, 3(4), 337-351.

O'Reilly, C. A., \& Tushman, M. L. (2013). Organizational ambidexterity: Past, present, and future. The Academy of Management Perspectives, 27(4), 324-338.

O'Dell, C., \& Hubert, C. (2011). The new edge in knowledge: How knowledge management is changing the way we do business. John Wiley \& Sons.

Ohno, T. (1988). Toyota production system: beyond large-scale production. crc Press.

O'Leary, D. E., \& Selfridge, P. (2000). Knowledge management for best practices. Communications of the $A C M, 43(11 \mathrm{es}), 11$.

Parry, G., Graves, A., \& James-Moore, M. (2008). Lean new product introduction: a UK aerospace perspective.

Rajagopalan, S. (2014). Review of the myths on original software development model. International Journal of Software Engineering \& Applications, 5(6), 103.

Ren, J., Yusuf, Y. Y., \& Burns, N. D. (2003). The effects of agile attributes on competitive priorities: a neural network approach. Integrated Manufacturing Systems, 14(6), 489-497.

Roemer, T. A., Ahmadi, R., \& Wang, R. H. (2000). Time-cost trade-offs in overlapped product development. Operations Research, 48(6), 858-865.

Saren, M. A. (1984). A classification and review of models of the intra-firm innovation process. $R \& D$ Management, 14(1), 11-24.

Shull, F. (2014). Progression, Regression, or Stasis?. IEEE software, 31(1).

Simon, H. A. (1991). Bounded rationality and organizational learning. Organization science, 2(1), 125-134.

Simon, H. A. (1996). The sciences of the artificial. MIT press.

Smith, R. P., \& Eppinger, S. D. (1997). A predictive model of sequential iteration in engineering design. Management Science, 43(8), 1104-1120.

Steward, T. A. (1997). Intellectual Capital: The New Wealth of Organizations, New York: Bantam Doubleday Dell Publishing Group. Inc.

Tautz, C., Althoff, K. D., \& Nick, M. (2000, March). A case-based reasoning approach for managing qualitative experience. In AAAI-00 Workshop on Intelligent Lessons Learned Systems (Vol. 236, p. 238).

Tuli, P., \& Shankar, R. (2015). Collaborative and lean new product development approach: a case study in the automotive product design. International Journal of Production Research, 53(8), 2457-2471.

Vandeville, J. V., \& Shaikh, M. A. (1999). A structured approximate reasoning-based approach for gathering "lessons learned" information from system development projects. Systems Engineering, 2(4), 242-247.

Von Zedtwitz, M. (2002). Organizational learning through post-project reviews in R\&D. $R \& D$ Management, 32(3), 255-268.

Weber, R., Aha, D. W., \& Becerra-Fernandez, I. (2001). Intelligent lessons learned systems. Expert systems with applications, 20(1), 17-34.

Weber, R., Aha, D. W., Muñoz-Ávila, H., \& Breslow, L. A. (2000, September). Active delivery for lessons learned systems. In European Workshop on Advances in Case-Based Reasoning (pp. 322-334). Springer Berlin Heidelberg.

Williams, T. M. (1999). Seeking optimum project duration extensions. Journal of the Operational Research Society, 50(5), 460-467.

Williams, T. (2007). Post-project reviews to gain effective lessons learned. Project Management Institute.

Williams, T. (2008). How do organizations learn lessons from projects-And do they?. IEEE Transactions on Engineering Management, 55(2), 248-266.

WT Lau, E. (2014). Empirical test of a new product evolutionary cycle. Journal of Product \& Brand Management, 23(1), 43-54.

Xiuhong, W. (2010, May). A Process Mode of Space Weapons Systems Innovation Based on the Knowledge Supply Chain. In E-Business and E-Government (ICEE), 2010 International Conference on (pp. 1727-1730). IEEE.

Zaidi, M. F. A., \& Othman, S. N. (2015). Organisational capabilities, environmental turbulence, and NPD performance: a study on Malaysian manufacturing firms. Procedia-Social and Behavioral Sciences, 172, 286-293.

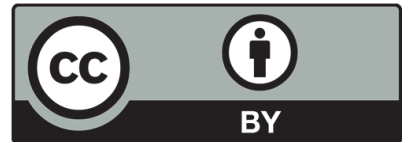

(C) 2016 by the authors; licensee Growing Science, Canada. This is an open access article distributed under the terms and conditions of the Creative Commons Attribution (CC-BY) license (http://creativecommons.org/licenses/by/4.0/). 